\section{JURNAL ABDIMAS

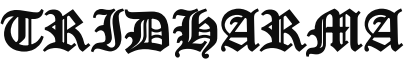 \\ AtA}

\title{
PENGELOLAAN POSISI KEUANGAN DAN EFEKTIFITAS KINERJA KEUANGAN DALAM PEMENUHAN KEBUTUHAN EKONOMI
}

\author{
Aria Aji Priyanto, Maghfiroh Yanuarti, Nurwita \\ Gos Ishak, Amun Soepandi \\ Dosen Ekonomi Fakultas Ekonomi Universitas Pamulang \\ Emaildosen01048@unpam.ac.id, dosen01089@unpam.ac.id,nurwita01917@unpam.ac.id, \\ dosen00595@unpam.ac.id, soepandi.amun@gmail.com
}

\begin{abstract}
ABSTRAK
Tujuan dari Kegiatan Pengabdian Kepada Masyarakat adalah untuk melaksanakan salah satu Tri Dharma Perguruan Tinggi. Selain itu diharapkan dapat memberikan informasi mngenai cara pengelolaan posisi keuangan dan efektifitas kinerja keuangan dalam pemunuhan kebutuhan ekonomi di kelurahan benda baru.

Metode pelaksanaan pengabdian ini dilakukan secara sistematis dan terbagi dalam beberapa kegiatan mulai dari tahap survei berupa sosialisasi yang dilakukan dengan menyusun program-program yang akan disampaikan saat kegiatan pengabdian masyarakat dilangsungkan. meliputi: penyusunan materi dan jadwal serta pembagian tugas tim pengabdian serta survei lokasi pengabdian. Tahap sosialisasi yaitu berupa silaturahmi dengan lurah dan jajarannya di kelurahan benda baru, menyampaikan maksud dan tujuan pengabdian serta hasil yang diharapkan. Pada tahap ini juga dilakukan perjanjian kerjasama pengabdian serta menentukan jadwal acara berlangsung. Tim pelaksana kegiatan pengabdian pada masyarakat adalah dosen Fakultas Ekonomi program studi Manajemen S1 beranggotakan 5 orang. Tim pengabdian akan memberikan materi pengelolaan posisi keuangan dan efektifitas kinerja keuangan dalam pemunuhan kebutuhan ekonomi oleh dosen UNPAM.

Hasil pengabdian masyarakat yang diperoleh adalah bertambahnya keilmuan bagi Para Peserta mengenai bagaimana cara pengelolaan posisi keuangan dan efektifitas kinerja keuangan dalam pemunuhan kebutuhan ekonomi di kelurahan benda baru, kegiatan ini merupakan kegiatan penyuluhan mengenai bagaimana pengelolaan posisi keuangan berupa asset, hutang dan modal. Dengan ilmu yang diperoleh pada kegiatan ini diharapkan mampu memberikan semangat baru bagi para dosen dan tenaga pengajar sebagai kontributor yang memotivasi khususnya bagi masyarakat sekitar yang membutuhkan.
\end{abstract}

\section{Kata Kunci : Posisi Keuangan, Kinerja Keuangan}

\section{PENDAHULUAN}

Perkembangan posisi keuangan mempunyai arti yang sangat penting bagi suatu perekonomian perusahaan maupun invidu. Untuk melihat sehat tidaknya suatu perusahaan tidak hanya dapat dilihat dari keadaan fisiknya saja, misalnya dilihat dari gedung pembangunan atau ekspansi. Faktor terpenting untuk dapat melihat perkembangan suatu perusahaan terletak dalam unsur keuangannya, karena dari unsur tersebut juga dapat mengevaluasi apakah kebijakan yang ditempuh suatu perusahaan.
Sudah tepat atau belum, mengingat sudah begitu kompleksnya permasalahan yang dapat menyebabkan kebangkrutan dikarenakan banyaknya perusahaan yang akhirnya gulung tikar karena faktor keuangan yang tidak sehat. Dengan keadaan sekarang ini, dimana persaingan yang ketat dalam bidang perekonomian sudah mulai masuk ke negara Indonesia, maka jika seorang manajer perusahaan tidak memperhatikan faktor kesehatan keuangan dalam perusahaannya mungkin saja akan terjadi kebangkrutan seperti yang telah dikemukakan di atas. 


\section{JURNAL ABDIMAS

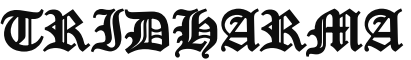 AtA}

Untuk menghindari kebangkrutan tersebut maka seorang manajer perusahaan sangat penting untuk selalu berusaha agar perusahaannya dapat terus berjalan atau dengan kata lain manajer tersebut dapat menjaga kelangsungan hidup perusahaannya yang ditempuh dengan cara selalu memperhatikan dan mengadakan evaluasi terhadap perkembangan perusahaannya dari waktu ke waktu. Seorang manajer harus dapat memahami kondisi keuangan tersebut akan mempengaruhi kelangsungan hidup perusahaan secara keseluruhan. Salah satu alat yang dapat dipakai untuk mengetahui kondisi keuangan, dalam hal ini tingkat kesehatan suatu perusahaan adalah terwujudnya laporan keuangan yang disusun pada setiap akhir periode yang berisi pertanggungjawaban dalam bidang keuangan atas berjalannya suatu usaha. Laporan finansial merupakan hasil dari proses akuntansi yang dapat digunakan sebagai alat berkomunikasi antara data finansial atau aktivitas suatu perusahaan dengan pihakpihak lain yang berkepentingan dengan data atau aktivitas tersebut. Data finansial yang dimaksud di atas adalah data yang tercermin dalam suatu laporan finansial, yang memberikan gambaran tentang keuangan suatu perusahaan yang berwujud neraca dan laporan rugi laba, dimana neraca mencerminkan tentang aktiva, kewajiban dan modal disuatu saat tertentu, sedangkan laporan rugi laba mencerminkan hasil yang telah dicapai suatu perusahaan selama periode waktu tertentu.

Pengabdian kali ini kami mengambil tema pengelolaan posisi keuangan dan efektifitas kinerja keuangan dalam pemenuhan kebutuhan ekonomi, pengabdian ini merupakan kegiatan penyuluhan yang dilakukan di kelurahan benda baru Tangerang Selatan sebagai sharing ilmu pengetahuan mengenai bagaimana pengelolaan posisi keuangan berupa asset, hutang dan modal. Asset merupakan sumber daya yang kita miliki, banyak orang atau perusahaan yang mempunyai asset namu tidak dapat memanfaatkannya dengan baik untuk menghasilkan sumber pendapatan, begitu juga hutang dan modal sebagai sumber dana yang memang penting untuk dikelola, jika salah mengelola sumber dana maka resiko terbesar kita akan kehilangan banyak asset. Pengelolaan posisi keuangan yang baik akan berdampak pada efektifitas kinerja keuangan, efektifitas kinerja keuangan dengan mengelola pendapatan secara maksimal dan mengelola beban seefisien mungkin yang pada dasarnya bahwa pengelolaan beban harus yang bersifat dibutuhkan dan urgensi. Maka dari itu kegiatan pengabdian kepada masyarakat ini bertujuan untuk sharing mengenai pengetahuan tentang posisi keuangan dan kinerja keuangan dalam pemenuhan kebutuhan ekonomi.

\section{RUMUSAN MASALAH}

Dengan mempertimbangkan latar belakang yang telah diutarakan di atas kami berinisiatif untuk membentuk pengabdian masyarakat yang ditujukan kepada para warga di kelurahan benda baru dengan memberikan penyuluhan mengenai pengelolaan posisi keuangan dan efektifitas kinerja keuangan dalam pemunuhan kebutuhan ekonomi yang dilakukan oleh dosen Universitas Pamulang. Yang beralamatkan di kelurahan benda baru, Pamulang, Tangerang Selatan.

\section{TUJUAN PELAKSANAAN}

1. Untuk memberi penyuluhan mengenai pengelolaan posisi keuangan dan efektifitas kinerja keuangan dalam pemunuhan kebutuhan ekonomi

2. Untuk memberi penyuluhan mengenai bagaimana pengelolaan posisi keuangan berupa asset, hutang dan modal.

\section{TINJAUAN PUSTAKA}

Mahmud M Hanafi dan Abdul Halim (2002:63) menyatakan bahwa Laporan posisi keuangan adalah laporan yang meringkas posisi keuangan suatu perusahaan pada tanggal tertentu. Laporan ini menampilkan sumber daya ekonomis (aset/aktiva), kewajiban ekonomis (hutang), modal, dan hubungan antar item tersebut. Sedangkan 


\section{JURNAL ABDIMAS

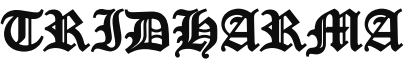 AtA}

P-ISSN 2715-7105, E-ISSN 2716-070X

Jurnal ABDIMAS Vol. 2, No. 1, Januari 2021,Hal (67-71)

@ Prodi Manajemen Fakultas Ekonomi Universitas Pamulang

Email: abdimasjurnal.unpam@gmail.com Telp: (021) 741-2566
Posisi keuangan perusahaan (business financial position) merupakan gambaran keadaan keuangan suatu perusahaan. Gambaran ini ditunjukkan oleh nilai dimiliki oleh perusahaan. Bagaimana mengetahui jumlah yang pasti dari kedua aspek tersebut. Caranya adalah dengan memanfaatkan neraca yang merupakan bagian dari laporan keuangan. Ada beberapa unsur yang wajib terdapat dalam sebuah neraca, yaitu aset (aktiva), liabilitas (utang), dan ekuitas. Aset adalah sumber yang dianggap akan bermanfaat bagi bisnis di kemudian hari. Di neraca, aset masuk dalam saldo normal debit. Liabilitas adalah utang yang dimiliki pada pihak lain dan harus dilunasi pada masa yang akan datang. Sementara itu, ekuitas adalah tuntutan pemilk terhadap modal di sebuah perusahaan. Sedangkan neraca adalah laporan yang sistematis tentang aktiva, utang, dan modal erusahaan pada suatu saat tertentu (biasanya disebut dengan satu periode akuntansi). Neraca menunjukkan jumlah investasi di dalam suatu perusahaan (Aktiva) dan sumber-sumber yang digunakan untuk investasi tersebut (Utang dan Modal). Oleh karena itu, neraca berisi jumlah Aktiva, Utang, dan Modal. Neraca merupakan perluasan dari persamaan dasar akuntansi, sehingga jumlah Aktiva $=$ Utang + Modal .

Kinerja keuangan merupakan prospek atau masa depan, pertumbuhan, dan potensi Perkembangan yang baik bagi perusahaan. Menurut Sutrisno (2009:53) Kinerja Keuangan perusahaan adalah prestasi yang dicapai perusahaan dalam suatu periode tertentu yang mencerminkan tingkat kesehatan perusahaan tersebut. Informasi Kinerja keuangan sangatlah diperlukan dalam menilai perubahan potensial sumber daya ekonomi untuk memprediksi kapasitas produksi dari sumber daya yang tersedia. Dengan kinerja keuangan, perusahaan dengan lebih mudah dapat mengetahui kondisi keuangan perusahaan di setiap periode tertentu baik menyangkut aspek penghipunan dana maupun penyaluran dana. Secara umum kinerja keuangan merupakan usaha yang dilakukan setiap perusahaan dalam mengukur dan menilai setiap keberhasilan yang dicapai dalam menghasilkan laba, sehingga perusahaan dapat melihat prospek, pertumbuhan, dan potensi perkembangan yang telah dicapai pada perusahaan. Suatu perusahaan dapat dikatakan berhasil apabila telah mencapai standar dan tujuan yang telah ditetapkan.

Adapun manfaat kinerja keuangan bagi sebuah perusahaan, berikut beberapa manfaatnya (1) Untuk mengetahu sejauh mana perkembangan perusahaan yang sudah di capai dalam setiap periode

tertentu. (2) Digunakan sebagai dasar perencanaan untuk perusahaan dimasa yang akan datang. (3) Dapat digunakan untuk menilai konstribusi suatu bagian dalam mencapai tujuan perusahaan secara

keseluruhan. (4) Dapat melihat kinerja perusahaan secara keseluruhan. (5) Sebagai penentuan penanaman modal agar dapat meningkatkan daya produksi suatu perusahaan. (6) Memberi arahan dalam membuat keputusan dan kegiatan perusahaan pada umumnya dan devisi

perusahaan pada khususnya.

Adapun beberapa Tujuan Kinerja Keuangan menurut Munawir (2007:31) adalah (1) Mengetahui Tingkat Likuiditas,

Likuiditas menunjukan kemampuan perusahaan untuk memenuhi kewajiban keuangan yang harus segera dilunasi pada saat ditagih. (2) Mengetahui Tingkat Solvabilitas, Solvabilitas menunjukan kemampuan perusahaan untuk memenuhi kewajiban keuangan baik dalam jangka panjang maupun jangka pendek. (3) Mengetahui Tingkat Rentabilitas, Rentabilitas menunjukan kemampuan perusahaan untuk memperoleh laba selama periode tertentu. (4) Mengetahui Tingkat Stabilitas, Stabilitas menunjukan kemampuan perusahaan dalam menjalankan usahanya dengan stabil yang diukur dengan mempertimbangkan kemampuan perusahaan untuk membayar atau melunasi setiap hutang dan beban bunga tepat pada waktunya.

Penilaian kinerja keuangan merupakan salah satu cara untuk memenuhi kewajiban terhadap investor dalam mencapai tujuan dan keinginan yang telah ditetapkan oleh perusahaan. Dengan bertambahnya kemajuan dan tingginya nilai usaha membuat 


\section{JURNAL ABDIMAS

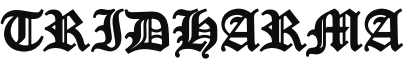 AtA}

P-ISSN 2715-7105, E-ISSN 2716-070X

Jurnal ABDIMAS Vol. 2, No. 1, Januari 2021,Hal (67-71)

@ Prodi Manajemen Fakultas Ekonomi Universitas Pamulang

Email: abdimasjurnal.unpam@ gmail.com Telp: (021) 741-2566 para investor melirik perusahaan tersebut untuk menanamkan modalnya sehingga akan terjadi kenaikan harga saham, atau dapat dikatakan bahwa harga

saham merupakan fungsi dari nilai perusahaan. Untuk menilai kinerja keuangan perusahaan, Anda dapat menggunakan Rasio atau indeks sebagai tolak ukur Anda untuk menilai dan menghubungkan dua data keuangan pada laporan keuangan perusahaan. Adapun beberapa perbandingan yang terdapat dalam jenis analisis rasio keuangan meliputi dua bentuk, yaitu pertama, perbandingan rasio antara satu perusahaan lain yang sejenis, dan kedua yaitu membandingkan rasio di masa lalu, saat ini, ataupun masa yang akan datang untuk perusahaan yang sama.

Penjelasan diatas sudah menjelaskan bagaimana kinerja keuangan bagi setiap perusahaan. Dalam perusahaan memang membutuhkan kinerja ini untuk mencapai setiap visi dan misi dalam mengembangkan perusahaan mereka.

Maka dari itu suatu perusahaan haruslah mengadakan evaluasi kinerja guna memenuhi tujuan-tujuan perusahaan, sehingga suatu perusahaan dapat berjalan dengan baik. Tentu dalam menelitinya perusahaan juga harus memperhatikan laporan pembukuan yang akurat dan tepat.

\section{HASIL DAN PEMBAHASAN}

Kegiatan Pengabdian Kepada Masyarakat yang didukung oleh Lembaga Penelitian dan Pengabdian Kepada Masyarakat (LPPM) Universitas Pamulang yang dilakukan oleh para dosen program studi Manajemen S1 telah berjalan dengan lancar dan mendapat apresiasi yang tinggi di tempat pelaksanaan kegiatan PKM tersebut yaitu di Kelurahan benda baru, Pamulang, Tangerang Selatan.

Harapan kami dengan pengabdian ini dapat memberikan informasi mengenai cara pengelolaan posisi keuangan dan efektifitas kinerja keuangan dalam pemunuhan kebutuhan ekonomi di kelurahan benda baru. dan dengan ilmu yang diperoleh pada kegiatan ini diharapkan mampu memberikan semangat baru bagi para dosen dan tenaga pengajar sebagai contributor yang memotivasi khususnya bagi masyarakat sekitar yang membutuhkan

\section{KESIMPULAN DAN SARAN \\ Kesimpulan}

Kesimpulan dari pengabdian ini adalah sebelumnya para peserta kurang mengerti tentang bagaimana mengelola posisi keuangan dan efektifitas kinerja keuangan dalam pemunuhan kebutuhan ekonomi. Setelah kegiatan PKM selesai dilakukan, masyarakat mendapatkan banyak manfaat secara langsung berupa moril dan materil sebagai bekal ilmu menghadapi tantangan di depan mata.

\section{Saran}

Dengan pengabdian ini, kami selaku pengabdi dapat memberikan wawasan mengenai pengelolaan posisi keuangan dan efektifitas kinerja keuangan dalam pemenuhan kebutuhan ekonomi di kelurahan benda baru. dan dengan ilmu yang diperoleh pada kegiatan ini diharapkan mampu memberikan semangat baru bagi para dosen dan tenaga pengajar sebagai contributor yang memotivasi khususnya bagi masyarakat sekitar yang membutuhkan, terlebih disaat pandemi masih berlangsung

\section{DAFTAR PUSTAKA}

Sutrisno. 2009. Manajemen Keuangan, Teori, Konsep dan aplikasi edisi kesembilan. Yogyakarta : Ekonisia.

Munawir, S. 2007. Analisa Laporan Keuangan edisis keempat. Yogyakarta : Liberty.

Mahmud M. Hanafi, dan Abdul Halim. 2003. Analisis Laporan Keuangan Tahunan. Yogyakarta : UPP AMP YKPN.

Pasaribu, V. L. D., Susanti, F., \& Hartuti, E. T. K. (2019). Memotivasi Siswa dan Siswi SMK Letris Indonesia di Dalam Menentukan Pilihan Untuk Melanjutkan Pendidikan Atau Bekerja Setelah Lulus Sekolah. Jurnal Pengabdian Dharma Laksana, 1(2), 161172. 


\section{JURNAL ABDIMAS

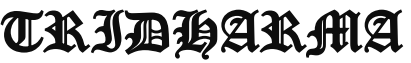

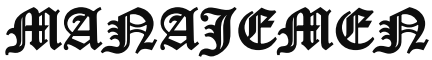

P-ISSN 2715-7105, E-ISSN 2716-070X

Jurnal ABDIMAS Vol. 2, No. 1, Januari 2021,Hal (67-71)

@ Prodi Manajemen Fakultas Ekonomi Universitas Pamulang

Email: abdimasjurnal.unpam@gmail.com Telp: (021) 741-2566
Pasaribu, V. L. D., Agrasadya, A., Shabrina, N., \& Krisnaldy, K. (2020). MENJADI ENTERPRENEUR MUDA YANG MEMILIKI JIWA LEADERSHIP UNTUK MENGHADAPI MASA DEPAN. Abdi Laksana, 1(1).

Pasaribu, V. L. D., Elburdah, R. P., Sudarso, E., \& Fauziah, G. (2020). PENGGUNAAN MANAJEMEN WAKTU TERHADAP PENINGKATAN PRESTASI BELAJAR DI SMP ARAISIYAH. Jurnal ABDIMAS Tri Dharma Manajemen, 1(1).

Pasaribu, V. L. D., Sulaiman, S., Sutiman, S., Thaharudin, T., \& Purnomo, B. Y. (2020). PENGENALAN LETAK POSYANDU TERDEKAT DIKELURAHAN PISANGAN DENGAN MANAJEMEN PEMASARAN REVOLUSI 4.0 UNTUK MENINGKATKAN PENGETAHUAN MASYARAKAT LETAK DAN FUNGSI POSYANDU TERDEKAT PADA KELURAHAN PISANGAN. DEDIKASI PKM, l(1), 105-110.

Pasaribu, V. L. D., Oktrima, B., Prabowo, B., Arianto, N., \& Haryoko, U. B. (2020). PROGAM PENDAMPINGAN DAN PENYELENGGARAAN PENDIDIKAN ANAK PADA USIA DINI TERHADAP PRESTASI BELAJAR DILINGKUNGAN RT 020 RW 009. KEL GIRI PENI. KEC WATES. YOGYAKARTA. JURNAL LOKABMAS KREATIF, I(1), 71-75.
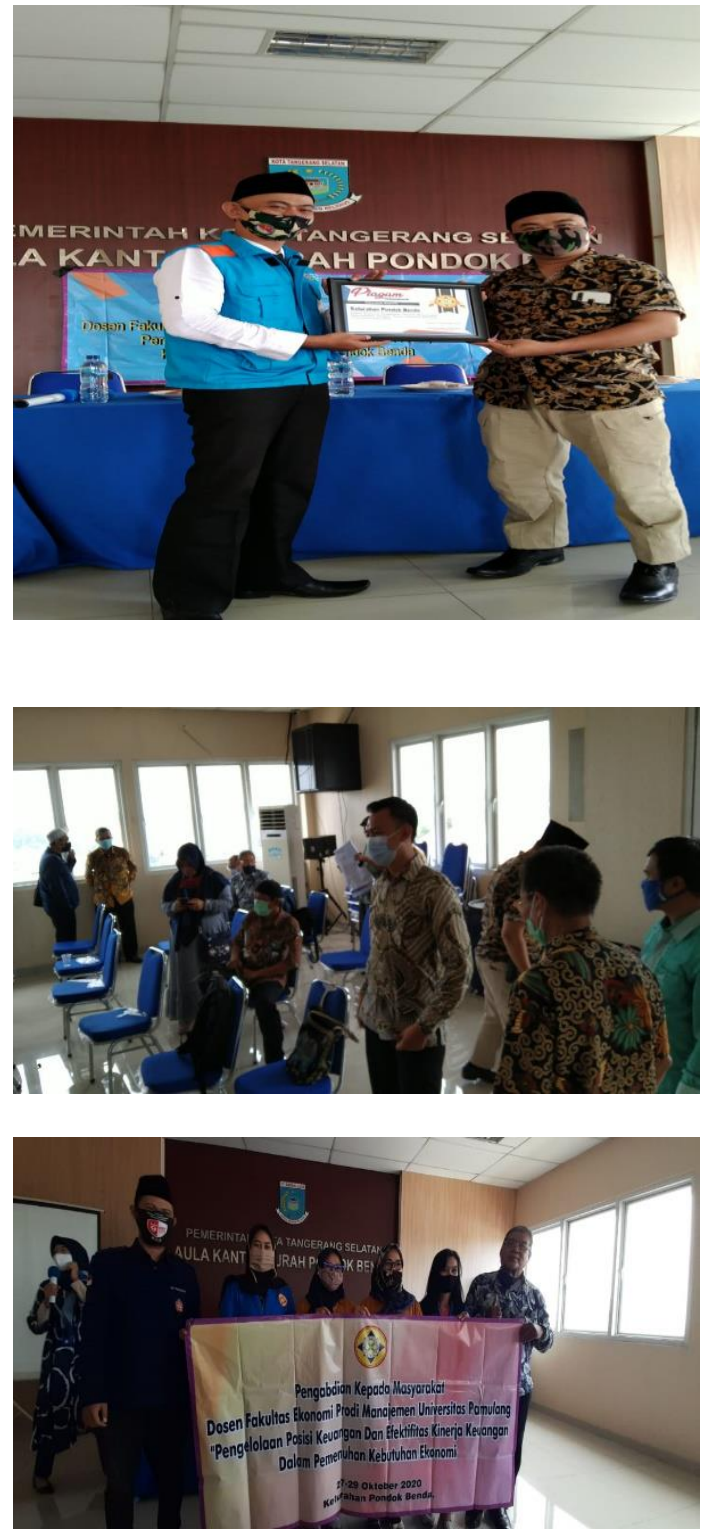

\section{DOKUMENTASI KEGIATAN}

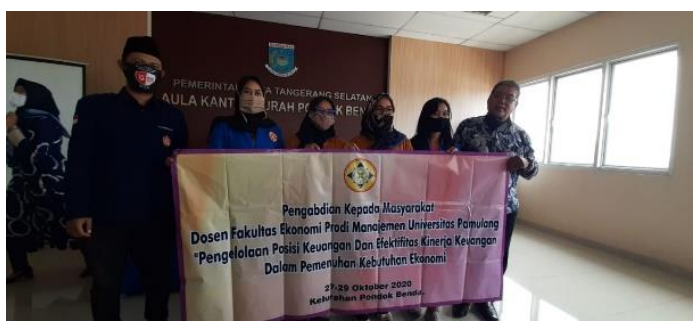

